\title{
PERIKANAN TANGKAP DI DANAU MATANO, MAHALONA, DAN TOWUTI, SULAWESI SELATAN
}

\author{
Samuel, Husnah, dan Safran Makmur \\ Peneliti pada Balai Riset Perikanan Perairan Umum, Mariana-Palembang \\ Teregistrasi I tanggal: 7 Mei 2008; Diterima setelah perbaikan tanggal: 15 Mei 2008; \\ Disetujui terbit tanggal: 6 Maret 2009
}

\begin{abstract}
ABSTRAK
Suatu penelitian untuk mengetahui aspek perikanan tangkap di Danau Matano, Mahalona, dan Towuti telah dilakukan dari bulan Mei-Desember 2005. Danau Matano, Mahalona, dan Towuti merupakan contoh dari ekosistem danau tektonik yang menampung jenis ikan endemik dan juga jenis ikan introduksi (tilapia dan ikan mas, Cyprinus carpio). Penelitian ini dilakukan dengan metode survei dengan cara mencari lokasi-lokasi ada aktivitas penangkapan ikan, wawancara dengan nelayan, dan bekerjasama dengan enumerator dalam mengumpulkan data penelitian. Hasil penelitian telah mendapatkan 22 jenis ikan endemik dan 6 jenis ikan introduksi yang tertangkap di ketiga danau (Matano, Mahalona, dan Towuti). Danau Matano tertangkap 7 jenis ikan endemik, Mahalona 8 jenis, dan Danau Towuti tertangkap 15 jenis. Jaring dan bagan merupakan alat tangkap yang dominan digunakan oleh nelayan untuk menangkap ikan endemik seperti ikan buttini (Glossogobius sp.) dan pangkilan (Telmatherina sp. dan Paratherina sp.). Hasil tangkapan ikan di Danau Towuti 5,7 kg per ha per tahun, Danau Mahalona 1,8 kg per ha per tahun, dan Danau Matano 1,2 kg per ha per tahun. Untuk melestarikan ikan-ikan endemik perlu ada pengelolaan dan pengaturan waktu dan lokasi penangkapan yang baik.
\end{abstract}

KATAKUNCI: Perikanan tangkap, spesies endemik, Danau Matano, Mahalona, Towoti

ABSTRACT: Capture fishery in Lakes of Matano, Mahalona, and Towuti, South Sulawesi. By: Samuel, Husnah, and Safran Makmur

A research in order to identify the capture fishery at Lakes: Matano, Mahalona, and Towuti was conducted from May to December 2005. Lakes Matano, Mahalona, and Towuti are examples of the representative tectonic lake ecosystems housing the endemic and some exotics (tilapia and carp, Cyprinus carpio) fish species. The survey methods were used in this reseacrh by hunting the location of fishing activities, interview with fishermen and partnership with enumerator in collecting research data. Results of the research show that 23 endemic fish species and 6 introduced per exotic fish species were caught in three research lakes. From 22 endemic fishes, 7 fish species were caught at Lake Matano, 8 fish species at Lake Mahalona, and 15 fish species were caught at Lake Towuti respectively. Gillnets and bagan were dominant fishing gears to catch the endemic fishes such as buttini (Glossogobius sp.) and pangkilan (Telmatherina sp. and Paratherina sp.). The productivity of the fisheries were $5.7 \mathrm{~kg}$ per ha per year for Lake Towuti, $1.8 \mathrm{~kg}$ per ha per year (Lake Mahalona), and $1.2 \mathrm{~kg}$ per ha per year (Lake Matano) respectively. To sustain endemic fishes is needed a better management eg. domesticating and regulating time and location of capture endemic fish species.

\section{KEYWORDS: capture fishery, endemic species, Lakes Matano, Mahalona, Towuti}

\section{PENDAHULUAN}

Pulau Sulawesi mempunyai banyak perairan umum daratan tipe danau yang dihuni berbagai jenis ikan endemik. Danau Matano, Mahalona, dan Towuti (Kompleks Danau Malili) terkenal mempunyai spesies ikan endemik terbesar di Pulau Sulawesi (Hadiaty \& Wirjoatmodjo, 2002) yang tidak dijumpai di pulau lain di Indonesia dan keragamannya tergolong tinggi. Menurut Tjahjo et al. (2005), jenis-jenis ikan endemik dominan tertangkap dengan alat tangkap jaring insang (gill nets) di Kompleks Danau Malili adalah ikan buttini (Glossogobius matanensis) dari famili Gobiidae, sedangkan di Danau Towuti yang merupakan danau terbesar di Kompleks Danau Malili, jenis ikan yang dominan tertangkap dengan alat bagan adalah ikan pangkilan (Paratherina sp. dan Telmatherina sp.) dari famili Telmatherinidae. Penangkapan ikan buttini dan pangkilan terjadi sepanjang tahun. Kelimpahan ikan endemik dari genus Paratherina berfluktuasi dengan puncak tertinggi pada bulan Nopember-Desember dan terendah pada bulan Juni (Nasution, 2005). Selanjutnya, jenis ikan endemik yang hanya hidup pada suatu perairan tertentu akan semakin langka dan berkurang kuantitasnya seiring dengan meningkatnya kegiatan eksploitasi tanpa diimbangi oleh kegiatan konservasi. 
Menurut informasi yang diperoleh dari seorang nelayan bagan di Danau Towuti, kegiatan perikanan tangkap khususnya ikan pangkilan dengan alat tangkap bagan baru berkembang pada awal 1990-an ketika mulai terbatasnya mata pencaharian penduduk setempat yang berasal dari penebangan dan penggergajian kayu gelondongan (sawmill). Sejak ada kegiatan perikanan tangkap di Kompleks Danau Malili sampai dengan kini, belum banyak tersedia data dan informasi dari dinas atau instansi terkait seperti dinas kelautan dan perikanan baik di tingkat kabupaten maupun propinsi tentang kegiatan perikanan tangkap di Kompleks Danau Malili. Dari faktor-faktor yang belum tersedia tersebut, maka salah satu kajian penting untuk dikatakan pada penelitian ini adalah tentang aktivitas penangkapan yang dilakukan oleh nelayan di ketiga danau tersebut. Tujuan dari penelitian ini adalah mendapatkan data tentang kegiatan penangkapan yang terdiri atas komposisi jenis ikan, hasil tangkapan nelayan, jenis dan jumlah alat tangkap, serta jumlah nelayan yang beroperasi pada perairan yang memiliki spesies endemik tinggi khususnya di Kompleks Danau Malili (Matano, Mahalona, dan Towuti).

\section{BAHAN DAN METODE}

Penelitian dilakukan pada bulan Mei, Juli, Oktober, dan Desember 2005 di Kompleks Danau Malili yaitu di Danau Matano, Mahalona, dan Towuti (Gambar 1). Pengambilan contoh dilakukan 4 kali yaitu Mei (survei pendahuluan dan penetapan enumerator) dan dilanjutkan dengan pengambilan contoh, monitoring, dan evaluasi hasil tangkapan ikan pada Juli, Oktober, dan Desember 2005. Pengumpulan data dan informasi dilakukan dengan 2 cara yaitu pengamatan atau pengambilan contoh langsung di lapangan dan pengumpulan data sekunder atau studi literatur. Untuk mendapatkan data dan informasi tentang jenis-jenis ikan yang ada di ketiga danau, dilakukan dengan cara mendatangi kampung-kampung nelayan dan lokasi penangkapan ikan oleh para nelayan dan juga dengan percobaan penangkapan. Percobaan penangkapan dilakukan dengan cara memasang sejenis jaring (gill nets) berukuran mata jaring (mesh size) rapat $(<5$ $\mathrm{mm}$ ) dengan ukuran panjang 80-100 $\mathrm{m}$ dan tinggi antara 1-1,25 $\mathrm{m}$ di habitat perairan yang ditumbuhi vegetasi (daerah litoral) dan pada perairan bebas (terbuka) sehingga mempunyai luas $100 \mathrm{~m}^{2}$. Di samping itu, dilakukan pula penangkapan ikan contoh dengan menggunakan listrik (Nakashizuka \& Stork, 2002). Contoh ikan selanjutnya difoto, diawetkan dalam larutan formalin (10\%) untuk diidentifikasi sampai tingkat spesies menurut Kottelat et al. (1993), kemudian spesies ikan yang telah diidentifikasi tersebut disimpan di museum untuk koleksi.
Data hasil tangkapan nelayan dikumpulkan oleh enumerator. Untuk Danau Matano ditunjuk 8 orang enumerator yang berprofesi sebagai nelayan jaring, Danau Mahalona 1 orang enumerator dari nelayan jaring, Danau Towuti 8 orang enumerator dari nelayan jaring dan 7 orang dari nelayan bagan. Data yang diperoleh dianalisis dengan cara menyusun ke dalam bentuk tabel yang terpola sehingga diperoleh nilainilai hasil tangkapan per upaya (catch per unit of effort) dari masing-masing jenis ikan per lokasi penelitian pada ketiga danau yang diamati.

Nilai hasil tangkapan per upaya (catch per unit of effort) disajikan dalam satuan jumlah bobot ikan yang tertangkap $(\mathrm{kg})$ dalam waktu 1 jam penangkapan oleh 1 unit alat tangkap jaring atau pukat dan atau 1 unit bagan. Satu unit jaring yang digunakan nelayan berukuran panjang $100 \mathrm{~m}$, lebar per tinggi $1,5 \mathrm{~m}$, dan ukuran mata jaring (mesh size) antara 1-2 inci. Data sekunder hasil tangkapan dikumpulkan dari instansi terkait untuk mengetahui keanekaragaman hayati ikan, produksi ikan tangkapan dan alat tangkap. Data dan informasi tersebut dikumpulkan melalui pertemuan teknis peneliti dari berbagai perguruan tinggi dan Pusat Penelitian dan Pengembangan Limnologi-Lembaga IImu Pengetahuan Indonesia. Data tersebut dipakai untuk melengkapi data dan informasi tentang keanekaragaman sumber daya hayati ikan di Pulau Sulawesi.

\section{HASIL DAN BAHASAN}

\section{Gambaran Umum Daerah Penelitian}

Pengelolaan sumber daya hayati dan alam di ketiga Danau (Matano, Mahalona, dan Towuti) oleh Pemerintah Daerah Propinsi Sulawesi Selatan berdasarkan SK. Menteri Pertanian No.274/Kpts/Um/ 4/1979 tanggal 24 April 1979 yang menetapkan ketiga danau tersebut menjadi Taman Wisata Alam. Data dan Informasi tentang luas, letak, dasar hukum, dan pengelolaan dari ketiga Taman Wisata Alam tersebut bersumber pada Balai KSDA Sulawesi Selatan II serta hasil pengamatan team survei.

\section{Danau Matano}

Danau Matano terletak di Kecamatan Nuha, Kabupaten Luwu Timur, Sulawesi Selatan pada koordinat $121^{\circ} 12^{\prime} 50^{\prime \prime}-121^{\circ} 28^{\prime} 24^{\prime \prime}$ BT dan $02^{\circ} 25^{\prime} 40^{\prime \prime}-$ 02'34'11" LS. Luas Danau Matano sekitar 16.075 ha, merupakan danau terdalam di Asia Tenggara dengan kedalaman mencapai 590 m (Hehanusa \& Haryani, 1999). Danau ini termasuk danau tektonik yang dapat dimanfaatkan untuk berbagai kegiatan yaitu wisata tirta yang dipadukan dengan kegiatan wisata minat 


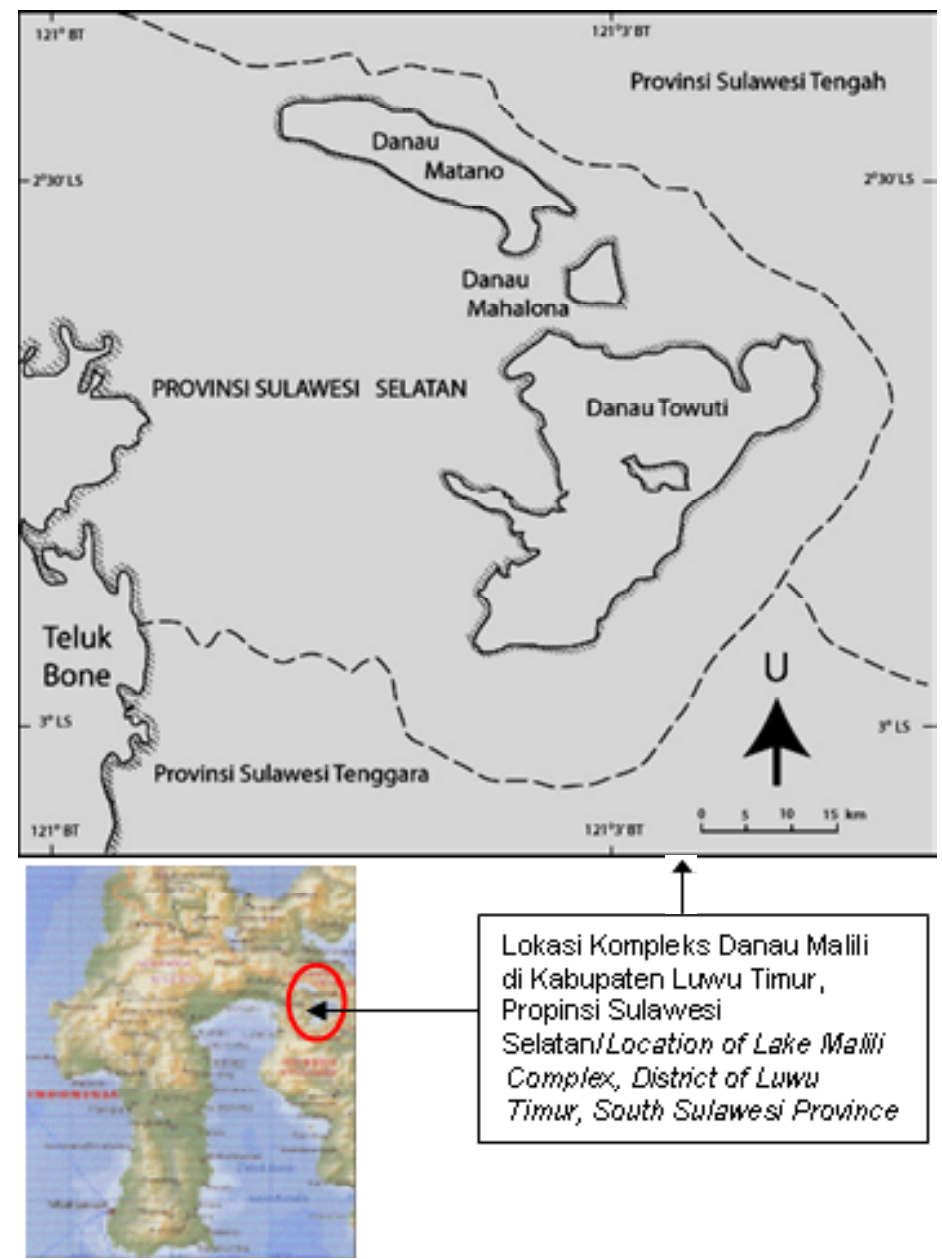

Gambar 1. Lokasi penelitian di kompleks Danau Malili (Matano, Mahalona, dan Towuti) Sulawesi Selatan. Figure 1. Research Location of Malili Lake Complex (Matano, Mahalona, and Towuti), South Sulawesi.

khusus, seperti rock climbing, caving, dan hiking. Panorama alam yang indah dapat dinikmati setiap saat, dari pagi hingga malam hari merupakan habitat alami dari beberapa jenis fauna. Danau ini merupakan habitat dari 13 jenis ikan air tawar endemik Sulawesi. Danau Matano juga merupakan habitat dari 76\% (27 jenis moluska) air tawar endemik Sulawesi (Whitten et al., 2002) dan habitat buaya (Crocodylus porosus, Hydrosaurus amboinensis, dan Enhydris matanensis).

\section{Danau Mahalona}

Luas Danau Mahalona adalah 2.317 ha, merupakan danau tektonik yang indah dan terbentuk dari lipatan perbukitan atau dari jalur sungai yang melebar antara Danau Matano dan Danau Towuti. Kedalaman airnya mencapai 73 m pada elevasi 300 $\mathrm{m}$ dpl. Arus dan gelombang air yang tenang membuat sangat aman untuk berwisata tirta. Sumber air berasal dari 3 sungai atau anak sungai yang salah satu antara lain aliran sungai dari Danau Matano. Pada danau ini, hidup secara alami 8 spesies ikan endemik
Sulawesi dan juga merupakan habitat alami buaya (Crocodylus porosus, Hydrosaurus amboinnensis dan Enhydris matanennsis). Danau Mahalona terletak di Kecamatan Towuti, Kabupaten Luwu Timur, Sulawesi Selatan pada koordinat antara 121 ${ }^{\circ} 27^{\prime} 53^{\prime \prime}-121^{\circ} 31^{\prime} 02^{\prime \prime}$ BT dan 02³3'44"-02³7'16" LS. Danau Mahalona adalah salah satu daya tarik untuk melaksanakan kegiatan wisata tirta. Aliran air dan gelombang cukup tenang. Buaya muara (Crocodylus porosus) dan soasoa (Hydrosarus amboinensis) serta 8 jenis ikan air tawar endemik merupakan penghuni Danau Mahalona. Kondisi lingkungan danau alami, karena tidak berbatasan dengan pemukiman penduduk dan jarang dikunjungi manusia.

\section{Danau Towuti}

Luas perairan Danau Towuti sekitar 56.627 ha, merupakan danau terluas kedua di Indonesia setelah Danau Toba dan kedalaman mencapai 203 m. Danau ini contoh perwakilan ekosistem danau tektonik, Danau Towuti dapat dimanfaatkan untuk berbagai 
Tabel 1. Beberapa jenis ikan yang tertangkap di Danau Matano, Towuti, dan Mahalona Table 1. Some fish species caught in Lake Matano, Mahalona, and Towuti

\begin{tabular}{|c|c|c|c|c|c|}
\hline No. & $\begin{array}{l}\text { Nama lokal/ } \\
\text { Local name }\end{array}$ & $\begin{array}{c}\text { Nama ilmiah/ } \\
\text { Scientific name }\end{array}$ & $\begin{array}{l}\text { Famili/ } \\
\text { Family }\end{array}$ & $\begin{array}{l}\text { Lokasi// } \\
\text { Location }\end{array}$ & $\begin{array}{c}\text { Keterangan/ } \\
\text { Remarks }\end{array}$ \\
\hline 1. & Kosang & Anabas testudineus & Anabantidae & $\begin{array}{l}\text { Matano, } \\
\text { Mahalona, Towuti }\end{array}$ & Introduksi \\
\hline 2. & Jangok & Trichogaster pectoralis & Belontiidae & Matano, Towuti & Introduksi \\
\hline 3. & Gabus & Channa striata & Channidae & $\begin{array}{l}\text { Matano, } \\
\text { Mahalona, Towuti }\end{array}$ & Introduksi \\
\hline 4. & Mujaer & Oreochromis mossambicus & Cichlidae & Matano, Towuti & Introduksi \\
\hline 5. & Lele & Clarias batrachus & Clariidae & Matano & Introduksi \\
\hline 6. & Mas & Cyprinus carpio & Cyprinidae & Matano, Towuti & Introduksi \\
\hline 7. & Buttini/Boto-boto & Glossogobius matanensis & Gobiidae & $\begin{array}{l}\text { Matano, } \\
\text { Mahalona, Towuti }\end{array}$ & Endemik \\
\hline 8. & Anggori & Glossogobius biocellatus & Gobiidae & $\begin{array}{l}\text { Mahalona, } \\
\text { Towuti, Matano }\end{array}$ & Endemik \\
\hline 9. & Bungok & Mugilogobius sp. & Gobiidae & Towuti & Endemik \\
\hline 10 & Anggori & Glossogobius intermedius & Gobiidae & Towuti & Endemik \\
\hline 11. & Anggori & Glossogobius celebius & Gobiidae & Towuti & Endemik \\
\hline 12. & Anggori & Glossogobius flavipinnis & Gobiidae & Towuti & Endemik \\
\hline 13. & Dui-Dui (hitam) & Dermogenys megarrhamphus & Hemiramphidae & Towuti, Mahalona & Endemik \\
\hline 14. & Dui-Dui (orange) & Dermogenys sp. & Hemiramphidae & Towuti & Endemik \\
\hline 15. & Dui-Dui & Dermogenys weberi & Hemiramphidae & Matano & Endemik \\
\hline 16. & Lunjar & Oryzias marmoratus & Oryziidae & Towuti & Endemik \\
\hline 17. & Masapi & Synbranchus sp. & Synbranchidae & Matano & $?$ \\
\hline 18. & Opudi & Telmatherina opudi & Telmatherinidae & Matano & Endemik \\
\hline 19. & Opudi & Telmatherina abendanoni & Telmatherinidae & Matano & Endemik \\
\hline 20. & Opudi & Telmatherina antoniae & Telmatherinidae & Matano & Endemik \\
\hline 21. & Opudi & Telmatherina prognatha & Telmatherinidae & Matano, Mahalona & Endemik \\
\hline 22. & Bonti-Bonti & Telmatherina bonti & Telmatherinidae & Mahalona, Towuti & Endemik \\
\hline 23. & $\begin{array}{l}\text { Bonti-bonti } \\
\text { (Ekor kuning) }\end{array}$ & Telmatherina sp. & Telmatherinidae & Mahalona, Towuti & Endemik \\
\hline 24. & Bonti-bonti & Telmatherina celebensis & Telmatherinidae & Mahalona, Towuti & Endemik \\
\hline 25. & Pangkilan lepang & Telmatherina sp. & Telmatherinidae & Towuti, Mahalona & Endemik \\
\hline 26. & Pangkilan sabe & Paratherina sp. & Telmatherinidae & Towuti & Endemik \\
\hline 27. & Pangkilan ekor merah & Telmatherina sp. & Telmatherinidae & Towuti & Endemik \\
\hline 28. & Pangkilan emas & Tominanga sanguicauda & Telmatherinidae & Towuti & Endemik \\
\hline
\end{tabular}

kegiatan wisata tirta yang dipadukan dengan kegiatan wisata minat khusus, seperti hiking. Panorama alam yang indah dapat dinikmati setiap saat dari pagi-malam hari. Danau ini memiliki beberapa pulau antara lain Pulau Loeha - pulau terbesar. Danau Towuti merupakan habitat dari beberapa jenis fauna yaitu 14 jenis ikan air tawar endemik dan 27 jenis moluska air tawar (87\%) endemik di Sulawesi (Whitten et al., 2002), serta buaya (Crocodylus porosus dan Hydrosaurus amboinensis) dan beberapa jenis satwa liar lain. Wilayah daratan antara lain dihuni oleh babi rusa (Babyrousa babyrussa dan Bubalus quarlesi). Kawasan perbukitan dengan pepohonan yang rimbun merupakan tempat hidup berbagai jenis burung. Danau Towuti terletak di Kecamatan Nuha, Kabupaten Luwu Timur, Sulawesi Selatan pada koordinat $121^{\circ} 20^{\prime} 48 "$ BT-12141'11" BT dan 02³8'22" LS$02^{\circ} 56^{\prime} 37^{\prime \prime}$ LS.

\section{Jenis Ikan yang Ditemukan}

Jenis ikan yang ditemukan di ketiga danau berjumlah 28 jenis (Tabel 1). Danau Matano dihuni oleh 15 jenis ikan, 7 jenis diantaranya adalah ikan endemik, antara lain Glossogobius matanensis, Glossogobius biocellatus, Telmatherina opudi, Telmatherina antoniae, Telmatherina prognatha, Dermogenys weberi, dan Synbranchus sp. Danau Towuti terdapat 21 jenis ikan, dan jumlah spesies endemik adalah 15 jenis, yaitu Glossogobius matanensis, Glossogobius biocellatus, Glossogobius intermedius, Glossogobius celebius, Glossogobius flavipinnis, Telmatherina celebensis, Telmatherina bonti, Telmatherina sp., Paratherina sp., Dermogenys megarrhamphus, Dermogenys sp., Mugilogobius sp., Oryzias marmoratus, dan Tominanga sanguicauda. Danau Mahalona didapatkan 11 jenis dan 8 jenis 
diantaranya adalah ikan endemik, yaitu Telmatherina celebensis, Telmatherina prognatha, Telmatherina bonti, Telmatherina sp., Paratherina sp., Dermogenys megarrhamphus, Glossogobius matanensis, dan Glossogobius biocellatus. Jenis ikan introduksi yang didapatkan adalah gabus (Channa striata), lele (Clarias batrachus), mujaer (Oreochromis mossambicus), mas atau karper (Cyprinus carpio), kosang (Anabas testudineus), dan jangok (Trichogaster pectoralis). Hasil penelitian ini tidak berbeda jauh dengan hasil penelitian Tjahyo et al. (2005) yang mendapatkan 14 spesies endemik di Danau Matano, 10 spesies di Danau Mahalona, dan 20 spesies di Danau Towuti.

\section{Hasil Tangkapan}

Fluktuasi hasil tangkapan ikan per satuan upaya (catch per unit of effort) dengan alat tangkap jaring di 3 danau (Matano, Mahalona, dan Towuti) (Gambar 2). Hasil tangkapan per upaya dengan alat tangkap jaring menunjukkan bahwa musim penangkapan ikan di Danau Matano terjadi pada bulan September dan Oktober dengan puncak penangkapan pada bulan Oktober. Di Danau Towuti musim penangkapan ikan dengan alat tangkap jaring terjadi pada bulan Juli, Agustus, September, Nopember, dan Desember. Demikian pula, puncak musim penangkapan di Danau Mahalona terjadi pada bulan Agustus. Di Danau Poso (Sulawesi Tengah) puncak musim penangkapan ikan terjadi pada bulan Juni-Agustus (Tjahjo et al., 2005). Untuk Danau Towuti, berdasarkan pada hasil wawancara dengan beberapa nelayan, mengatakan bahwa hasil tangkapan tertinggi untuk jenis ikan buttini dan pangkilan terjadi pada saat musim kemarau di waktu musim bulan gelap (saat cuaca cerah dan di malam hari ikan pangkilan mendekati cahaya lampu datang secara bergerombolan, karena tidak terhalang oleh hujan dan pada waktu tersebut hasil tangkapan tinggi). Demikian pada, musim kemarau (bulan JuliAgustus) merupakan puncak musim penangkapan ikan di Danau Towuti.

Jenis ikan yang dominan tertangkap dengan alat tangkap jaring (Tabel 2 , 3, 4) adalah ikan buttini, mujaer, dan mas. Pada Tabel 2, hasil tangkapan per upaya untuk ikan buttini di Danau Matano berkisar 0,47-1,46 kg per jam per jaring (rata-rata 1,24 kg per jam per jaring), ikan mujaer 0,12-0,98 kg per jam per jaring (rata-rata 0,56 kg per jam per jaring) dan ikan mas 0,05-0,96 kg per jam per jaring (rata-rata 0,44 kg per jam per jaring). Di Danau Towuti, hasil tangkapan per upaya untuk ikan buttini berkisar 0,09-1,05 kg per jam per jaring (rata-rata 0,51 kg per jam per jaring), ikan mujaer antara 0,31-3,54 kg per jam per jaring (rata-rata 1,2 kg per jam per jaring) (Tabel 3). Di Danau Mahalona, hasil tangkapan per upaya ikan buttini antara 0,1-1,30 kg per jam per jaring (rata-rata 0,76 $\mathrm{kg}$ per jam per jaring) dan ikan mujaer 0,1-0,53 kg per jam per jaring (rata-rata 0,31 kg per jam per jaring) (Tabel 4). Berdasarkan atas data di Danau Matano dan Mahalona, tujuan penangkapan dengan alat tangkap jaring ditujukkan pada ikan buttini, sedangkan di Danau Towuti sebaliknya, penangkapan dengan alat jaring lebih ditujukan pada ikan introduksi (mujaer).

Dari kenyataan tersebut dapat diketahui bahwa penangkapan ikan buttini merupakan tujuan utama nelayan di Matano. Hal tersebut dikarenakan masyarakat sekitar Danau Matano beranggapan bahwa ikan buttini merupakan ikan konsumsi ekonomis dan mempunyai cita rasa yang lebih enak dibandingkan dengan ikan buttini dari Danau Towuti. Sebaliknya, di Danau Towuti ternyata ikan mujaer merupakan jenis ikan dominan hasil tangkapan nelayan jaring. Populasi ikan introduksi (mujaer) di

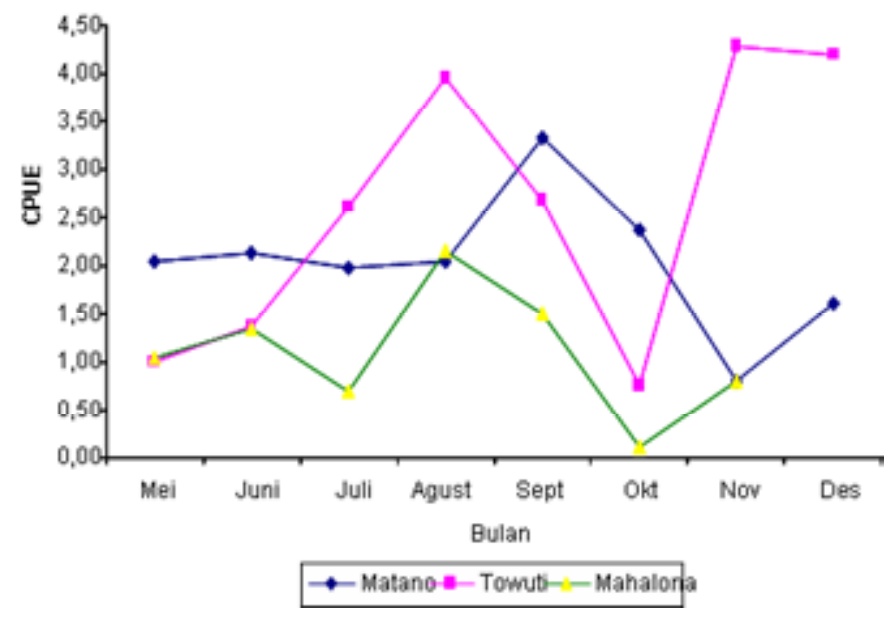

Gambar 2. Hasil tangkapan ikan (catch per unit of effort) di Danau Matano, Mahalona, dan Towuti. Figure 2. Catch per unit effort in Lake Matano, Mahalona, and Towuti. 
Tabel 2. Hasil tangkapan ikan dengan alat tangkap jaring di Danau Matano

Table 2.

Fish species caught by gill nets in Lake Matano

\begin{tabular}{lcccccc}
\hline \multirow{2}{*}{$\begin{array}{c}\text { Bulan/ } \\
\text { Mounth }\end{array}$} & \multirow{2}{*}{ CPUE (kg/jam) } & \multicolumn{5}{c}{ CPUE (kg/jam) per jenis ikan } \\
\cline { 3 - 7 } & 2,05 & Buttini & Mas & Mujaer & Kosang & Gabus \\
\hline Mei & 2,12 & 1,46 & 0,61 & 0,98 & - & - \\
Juni & 1,98 & 1,44 & 0,31 & 0,37 & - & - \\
Juli & 2,04 & 1,31 & 0,05 & 0,80 & - & - \\
Agustus & 3,32 & 1,41 & - & 0,69 & 0,04 & 0,04 \\
September & 2,38 & 1,29 & 0,96 & 0,88 & 0,03 & - \\
Oktober & 0,81 & 0,47 & - & 0,38 & - & - \\
Nopember & 1,60 & 1,37 & 0,11 & 0,34 & - & - \\
Desember & $\mathbf{2 , 0 4}$ & & & & & \\
\hline Rata-rata & &
\end{tabular}

Sumber data/Data sources: pencatatan hasil tangkapan ikan oleh nelayan jaring Danau Matano yang dipilih sebagai enumerator

Tabel 3. Hasil tangkapan ikan dengan alat tangkap jaring di Danau Towuti

Table 3. Fish species caught by gill nets in Lake Towuti

\begin{tabular}{lccccccc}
\hline \multicolumn{1}{c}{$\begin{array}{c}\text { Bulan/ } \\
\text { Mounth }\end{array}$} & $\begin{array}{c}\text { CPUE } \\
\text { (kg/jam) }\end{array}$ & Mujaer & Buttini & Mas & Bonti & Pangkilan & Anggori \\
\hline Mei & 1,01 & 0,32 & 0,63 & 0,06 & - & - & - \\
Juni & 1,36 & 0,31 & 1,05 & - & - & - & - \\
Juli & 2,60 & 0,85 & 0,34 & 1,15 & 0,26 & - & - \\
Agustus & 3,96 & 3,54 & 0,09 & 0,09 & 0,02 & 0,22 & - \\
September & 2,68 & 1,98 & 0,15 & 0,54 & 0,01 & - & - \\
Oktober & 0,77 & 0,77 & - & - & - & - & - \\
Nopember & 4,28 & 1,31 & 0,88 & 0,77 & 0,01 & 1,28 & 0,03 \\
Desember & 4,19 & 0,46 & 0,44 & 0,87 & 0,01 & 2,41 & - \\
\hline Rata-rata & $\mathbf{2 , 6 1}$ & \multicolumn{7}{c}{}
\end{tabular}

Sumber data/Data sources: pencatatan hasil tangkapan ikan oleh nelayan jaring Danau Towuti yang dipilih sebagai enumerator

Tabel $4 . \quad H a s i l$ tangkapan ikan dengan alat tangkap jaring di Danau Mahalona

Table 4.

Fish species caught by gill nets in Lake Mahalona

\begin{tabular}{lccccc}
\hline \multicolumn{1}{c}{$\begin{array}{c}\text { Bulan/ } \\
\text { Mounth }\end{array}$} & $\begin{array}{c}\text { CPUE } \\
(\mathbf{k g} / \mathbf{j a m})\end{array}$ & Buttini & \multicolumn{4}{c}{ MPUE (kg/jam) per jenis ikan } \\
\cline { 3 - 6 } & 1,04 & 0,51 & 0,53 & Kosang & Gabus \\
\hline Mei & 1,35 & 1,12 & 0,23 & - & - \\
Juni & 0,70 & 0,60 & 0,10 & - & - \\
Juli & 2,16 & 1,30 & 0,40 & 0,04 & 0,42 \\
Agustus & 1,50 & 1,20 & 0,30 & - & - \\
September & 0,10 & 0,10 & - & - & - \\
Oktober & 0,80 & 0,50 & 0,30 & - \\
Nopember & $\mathbf{1 , 0 9}$ & & & & \\
\hline Rata-rata & & &
\end{tabular}

Sumber data/Data sources: pencatatan hasil tangkapan ikan oleh nelayan jaring Danau Mahalona yang dipilih sebagai enumerator

Tabel $5 . \quad$ Hasil tangkapan ikan dengan alat tangkap bagan di Danau Towuti

Table 5.

Fish species caught by gillnets in Lake Towuti

\begin{tabular}{lcccccccc}
\hline \multicolumn{1}{r}{$\begin{array}{c}\text { Bulan/ } \\
\text { Mounth }\end{array}$} & $\begin{array}{c}\text { CPUE } \\
\text { (kg/jam) }\end{array}$ & Mujaer & Bottini & Mas & Bonti & Pangkilan & Udang & Anggori \\
\hline Mei & 2,26 & - & 1,63 & - & 0,01 & 0,56 & 0,06 & - \\
Juni & 4,02 & - & 0,11 & - & - & 3,48 & 0,40 & 0,03 \\
Juli & 3,22 & - & 2,51 & - & 0,02 & 0,69 & - & - \\
Agustus & 2,30 & - & 1,59 & - & - & 0,71 & - & - \\
September & 3,17 & - & 2,06 & - & - & 1,11 & - & - \\
Oktober & 7,20 & - & 4,05 & - & - & 3,15 & - & - \\
Nopember & 1,79 & - & - & - & 0,01 & 1,78 & - & - \\
Desember & 1,93 & - & 0,01 & - & 0,01 & 1,85 & - & 0,06 \\
\hline Rata-rata & $\mathbf{3 , 2 4}$ & \multicolumn{7}{c}{}
\end{tabular}

Sumber data/Data sources: pencatatan hasil tangkapan ikan oleh nelayan bagan Danau Towuti yang dipilih sebagai enumerator 


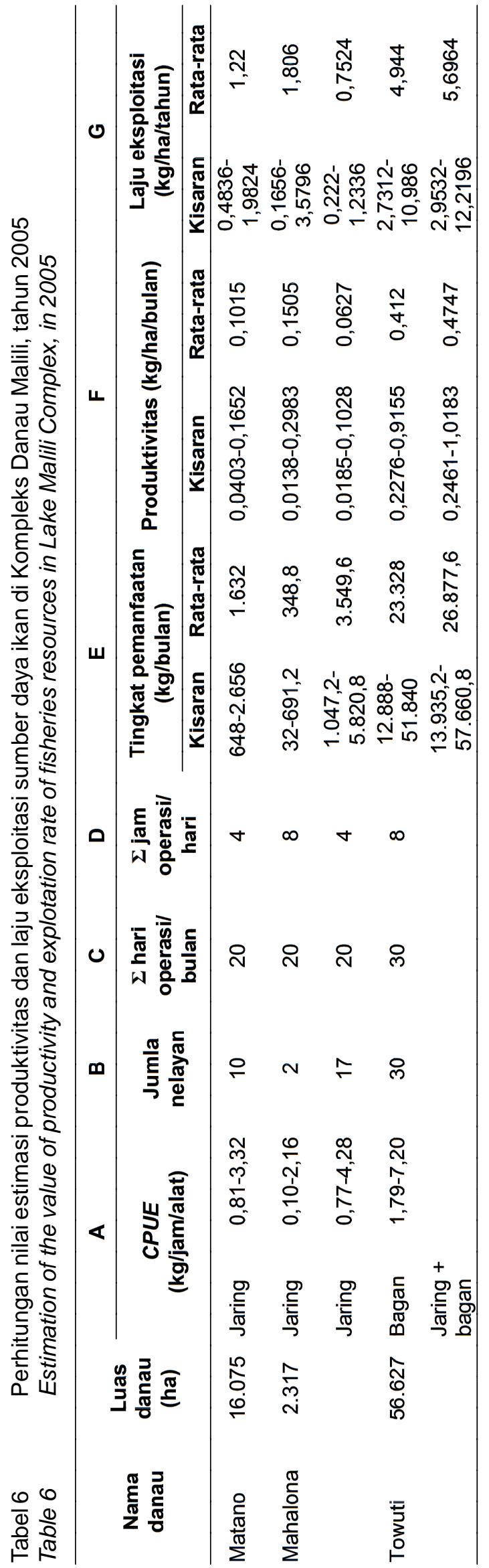


perairan Danau Towuti meningkat cepat. Hal tersebut dikarenakan sifat reproduksi yang cepat (3 bulan memijah) dan kebiasaan makan ikan mujaer yang omnivora menjadikan populasi ikan tersebut meningkat cepat. Hal yang sama juga terjadi pada ikan mas. Walaupun tidak sebanyak mujaer, ikan mas juga merupakan ikan dominan di Kompleks Danau Malili (khususnya di Danau Towuti). Hasil tangkapan beberapa nelayan bahkan mencapai di atas $20 \mathrm{~kg}$ per ekor. Turunnya hasil tangkapan ikan buttini kemungkinan diakibatkan oleh penurunan populasinya di alam. Hal ini selain karena eksploitasi ikan tersebut, kemungkinan juga karena degradasi lingkungan akibat dari penebangan pohon dan pencemaran air dari PT. INCO.

Alat tangkap bagan hanya beroperasi di Danau Towuti, merupakan bagan bergerak. Jumlahnya saat ini mencapai lebih dari 30 unit bagan. Bagan dioperasikan pada malam hari dengan lokasi bersifat tetap (stationer) dan dapat dipindah-pindahkan. Tabel 5 menunjukkan musim penangkapan dengan menggunakan alat tangkap bagan pada bulan Juni Oktober dengan puncaknya pada Oktober. Ikan pangkilan adalah jenis ikan yang menjadi tujuan utama penangkapan oleh alat tangkap bagan, diikuti oleh butini dan jenis lainnya.

Hasil tangkapan per upaya (catch per unit of effort) untuk ikan pangkilan berkisar 0,56-3,48 kg per jam per bagan (rata-rata 1,68 kg per jam per bagan), ikan buttini 0,01-4,05 kg per jam per bagan (rata-rata 1,70 kg per jam per bagan) (Tabel 5). Aktivitas penangkapan dengan jaring di Danau Matano ditujukan untuk menangkap ikan buttini, sedangkan di Danau Towuti, ikan buttini tertangkap dengan jaring dan bagan. Hasil tangkapan utama dengan alat tangkap bagan di Danau Towuti ditujukan pada ikan-ikan kecil jenis pangkilan yang merupakan kumpulan dari berbagai jenis ikan endemik seperti Dermogenys, Paratherina, Telmatherina, Tominanga, dan Oryzias serta berbagai jenis Glossogobius (Soeroto, 2004). Pengelolaan yang perlu dilakukan untuk Danau Matano adalah pengaturan penangkapan ikan buttini, sedangkan untuk Danau Towuti adalah pengelolaan alat tangkap bagan yang menangkap ikan pangkilan dan butini.

\section{Produktivitas Sumber Daya Ikan}

Produktivitas sumber daya ikan memberikan gambaran tentang seberapa besar sumber daya ikan yang dapat dimanfaatkan atau ditangkap oleh nelayan dalam suatu luasan perairan dan periode waktu tertentu. Parameter yang digunakan untuk menghitung nilai produktivitas sumber daya ikan adalah hasil tangkapan per upaya, jumlah nelayan, jumlah hari tangkap dalam 1 bulan, jumlah jam tangkap dalam 1 hari dan luasan perairan dalam satuan hektar. Dengan demikian nilai pemanfaatan yang diperoleh adalah satuan $\mathrm{kg}$ ikan tertangkap per hektar per bulan atau $\mathrm{kg}$ ikan tertangkap per hektar per tahun. Untuk mengetahui nilai produktivitas dan laju eksploitasi sumber daya ikan di masing-masing danau dalam Kompleks Danau Malili digunakan data hasil tangkapan ikan per jenis alat tangkap atau catch per unit of effort (Tabel 2, 3, 4, dan 5), jumlah nelayan tangkap, jumlah jam operasi menangkap ikan dalam 1 hari, dan jumlah hari operasi menangkap ikan dalam 1 bulan. Hasil perhitungan di masing-masing danau tercantum pada Tabel 6 .

Hasil pengamatan pada nelayan di kompleks Danau Malili menunjukkan bahwa kegiatan penangkapan ikan merupakan kebutuhan untuk memanfaatkan potensi sumber daya ikan yang ada, baik itu berupa jenis ikan endemik maupun ikan yang telah lama diintroduksi dan berkembang di tempat tersebut. Pemanfaatan potensi sumber daya perikanan perairan umum di ketiga danau yaitu Towuti, Mahalona, dan Matano terkesan belum optimal dan belum banyak dilakukan usaha-usaha untuk pengembangan dan peningkatan produksi perikanan. Tabel 6 terestimasi bahwa laju eksploitasi sumber daya ikan di Danau Matano, Mahalona, dan Towuti berdasarkan pada hasil survei, nilai rata-rata masingmasing 1,2 kg per hektar per tahun (Danau Matano), $1,8 \mathrm{~kg}$ per hektar per tahun (Danau Mahalona), dan $5,7 \mathrm{~kg}$ per hektar per tahun (Danau Towuti).

\section{KESIMPULAN DAN SARAN}

1. Kegiatan penangkapan di ketiga danau banyak ditujukan pada ikan endemik buttini (oleh alat tangkap jaring dan pangkilan oleh alat tangkap bagan. Laju eksploitasi sumber daya ikan atau tingkat pemanfaatan ikan di Danau Matano ada 1,2 kg per hektar per tahun, Danau Mahalona 1,8 kg per hektar per tahun, dan Danau Towuti 5,7 kg per hektar per tahun.

2. Pengelolaan jenis ikan endemik (Glossogobius sp., Dermogenys sp., Paratherina sp., Tominanga sp., Oryzias sp., dan Telmatherina sp.) perlu dilakukan melalui domestikasi dan pengaturan waktu dan lokasi penangkapan.

\section{PERSANTUNAN}

Kegiatan dari hasil riset keanekaragaman ikan endemik di perairan Sulawesi, T. A. 2005, di Pusat Riset Perikanan Tangkap-Ancol, Jakarta. 


\section{DAFTAR PUSTAKA}

Hadiaty, R. K. \& S. Wirjoatmodjo. 2002. Studi pendahuluan biodiversitas dan distribusi ikan di Danau Matano, Sulawesi Selatan. Jurnal Iktiologi Indonesia. 2 (2): 23-29.

Hehanusa, P. E. \& G. S. Haryani. 1999. Morfologi cekungan dan profil suhu Danau Matano dan Danau Poso. Limnotek Perairan Darat Tropis di Indonesia Indonesia. VI (1). 13-22.

Kottelat, M., A. J. Whitten, S. N. Kartikasari, \& S. Wiroatmodjo. 1993. Freshwater Fishes of Western Indonesia and Sulawesi (Ikan Air Tawar Indonesia Bagian Barat dan Sulawesi). Periplus Editions Ltd. Indonesia.

Nakashizuka, T. \& N. Stork. 2002. Biodiversity Research Methods: IBOY in Western Pacific and Asia. Kyoto University. Press and Trans Pacific Press. Melbourne. 216 pp.

Nasution, S. H. 2005. Karakteristik habitat, aspek biologi, dan upaya pengelolaan ikan endemik
Telmatherina celebensis di Danau Towuti. Dipresentasikan pada Pertemuan Pakar Perikanan. Badan Riset Kelautan dan Perikanan. Pusat Riset Perikanan Tangkap. Jakarta. 26 pp.

Soerato, B. 2004. The Biodiversity and the Management Strategi of Endemic Fish Spesies in Lake Towuti, South Sulawesi, Indonesia. The Asian Regional Centre for Biodiversity Conservation and the European Commission. 26 pp.

Tjahyo, D. W. H., Husnah, D. Oktaviani, A. S. Nastiti, S. E. Purnamaningtyas, \& D. Nugroho. 2005. Riset keanekaragaman hayati ikan perairan pedalaman di Sulawesi. Dipresentasikan pada Pertemuan Pakar Perikanan. Badan Riset Kelautan dan Perikanan. Pusat Riset Perikanan Tangkap. Jakarta. 85 pp.

Whitten, A. J., M. Mustafa, \& G. S. Henderson. 2002. Ekologi Sulawesi. Yogyakarta. Universitas Gajah Mada. p. 708-719. 